\title{
Youth Crises and Conventional Policing in Nigeria: A Political Economy Analysis
}

\section{Tedheke Moses EU*}

Department of Political Science and Defence Studies, Faculty of Arts and Social Science, Nigeria Defence Academy, Kaduna, PMB 2109, Nigeria

*Corresponding author: Tedheke Moses EU, Department of Political Science and Defence Studies, Faculty of Arts and Social Science, Nigeria Defence Academy, Kaduna, PMB 2109, Nigeria, Tel: +2348106605692; E-mail: tedheke@hotmail.com

Received date: March 21, 2016; Accepted date: March 25, 2016; Published date: March 31, 2016

Copyright: (c) 2016 Tedheke Moses EU. This is an open-access article distributed under the terms of the Creative Commons Attribution License, which permits unrestricted use, distribution, and reproduction in any medium, provided the original author and source are credited.

\begin{abstract}
Most studies in social issues in this age of hyper-imperialism which is globalization or neo-liberalism see such phenomena from the point of view of eclecticism. In other words, they see issues one-sidedly neglecting their interconnections and their concatenations which dialectics always bring out in very clear focus. The same is very true of youth crisis resulting from youth bulge locally and internationally. In such partial focus on issues, clues to crises generating dynamics are papered over which have been the case of youth crises in Nigeria, Africa, the Third World and beyond. As a result of the lack of fundamentals in the analysis of youth crises or bulge the task of conventional policing becomes increasingly difficult if not impossible. Youth bulge is a product of global underdevelopment. It is the product of collaboration between the local agents of neo-liberalism (in this case Nigerian rentier or comprador bourgeoisie) and their international mentors, the advanced capitalist bourgeoisie of Europe, North America and Japan. It is a product of relative over population, relative to means of employment generated by the system, and not to the means of subsistence. The youth crises is equally a product of an abnormal state that has deviated from the dynamics of classical state formation based on the internal emergence of a dominant class but which structures in Nigeria have been attenuated by the external imposition of the state strengthening its abnormalities. It has created vampire-victim relations making Nigeria, Africa and indeed the Third World the victim of imperialism or the vampire. This study has found out that superfluous population is a creation of the type of a global political economy which has resulted in youth bulges here and there. It is a product of global criminal political economy of neo-liberalism. This economy of globalization has removed the state world-wide from social provisioning hindering the welfare state. In this process, the unemployed becomes criminalized making the task of conventional policing increasingly difficult.
\end{abstract}

Keywords: Dialectics; Eclecticism; Criminalization; Imperialism; Pauperization

\section{Introduction}

Most studies of the youth in Nigeria, Africa and indeed the so-called developing countries employ eclectic approaches rather than a holistic world view. Eclectism is a senseless jumble of materialism and idealism (Marx, Engels and Lenin 1977:231). The dominant approaches tend to demonize the victims of national and global criminal political economy. This approach makes one to see issues from a unilateral perspective preventing one from having an overall view of any issue in this case, the youth question. However, the political economy approach removes one from the one-sidedness in perspective and places issues of the youth question in a broader perspective of dialectics. Instead of the unilateral posturing of the conventional social science, it exposes the interconnections between the internal and external or the endogenous and exogenous factors in the dynamics of youth crisis. This approach gives us the structures that are fueling the youth crises both internally and globally and how such crises are growing beyond conventional policing. The attendant crises throughout the whole world in this period of neo-liberalism have called for extra-policing activities [1].

The youth question in Nigeria and beyond is the part of the national question. The national question is not just the very narrow nationality question. The youth question and nationality or ethnic question are part of the national question which is the developmental or national security question. Eclecticism or one-sided analysis can only result in a very partial view of the issues in the national question and indeed the youth question or crises and will make us to demonize the youth thus complicating the question of conventional policing, equally a part of the national security question. One would suspect that the one-sided approach in a social analysis is what Paul Collier calls the single-factor theories based on intense compartmentalization of disciplines which has gained upper hand in various studies leading to pervasive development failures. Collier [2] said that the part of the reason singlefactor theories about developmental failures is so common are those modern academics tending to specialize: they are trained to produce intense but narrow beams of light.

However, the same "narrow beam of light" which Paul Collier was trying to avoid he fell a victim to in his analysis of the causes of the African crises of the Post-Cold War. Collier [3] says that with the arrival of peace in the most powerful countries, the scale of warfare has diminished: we now have small war in small countries. Usually, the violence is internal; the country tears itself apart while the rest of the world watches. The uncomfortable fact is that a large group of impoverished little countries remain structurally dangerous (emphasis is the original). Wars in the bottom billion are nasty, brutish and long, Paul Collier concludes. However, the same narrow beam of light which Paul Collier despises him inadvertently embraces as he sees the Africa crises beyond conventional policing as internal in causations neglecting their external dimensions. The reductionist inclinations which Paul Collier sees as the problem of modern academics would 
make him not to appreciate the international dimensions of such issues. Collier [2] pigeon - holed himself as he sees the three characteristics that make states globally to be prone to civil wars (or conflicts) as low income, slow growth and dependence upon primary commodity exports.

Paul Collier said that such conflicts arising from the excruciating slow death of the other half (the underdevelopment countries) would pose security nightmare for the world of our children. One is convinced beyond equivocation that the nightmare is already here with us in the form of youth restiveness or extra-ordinary-youth crises in the various shapes across the globe but more intense in the periphery of capital. As in Nigeria, it poses the internal security crises, such as the Boko Haram, the Niger-Delta crises amongst others beyond conventional policing. The extra-ordinary youth crises (arising from youth bulge) are growing beyond conventional policing in Nigeria and most of the Third World because of the nature and character of advance capital and backward capital of the peripheries that generates structural violence through what Karl Marx calls the reserved army of the unemployment. This has resulted in the emergence of the repressive state. In the view of Arowosegbe [3] there has been no proper systematic linkage between repressive state policies and the adoption of violent behavior as a strategy for articulating group disaffections. This linkage he sees as his contribution in filling the gap that has existed in the analysis of youth crises in Niger-Delta. Jeremiah O. Arowosegbe equally identified conservative politics (whatever that means) as one of the key problems that has escalated the youth crisis in the Niger-Delta in particular and Nigeria in general.

Paul Collier rightly identifies poverty as the cause of the insecurity of the Bottom Billion and came later in 2010 to talk about The Plundered Earth, giving the formula for its solution but, which formula is rather palliative than an alternative strategy. In the same vein Arowosegbe identified just only the internal dynamics of the extraordinary youth crises in Nigeria and neglects its external dimension. It is this one-sidedness that makes him to identify the repressive Nigerian State instead of locating it within the global Super-state of multilateral imperialism. It has to be understood that the repressive Nigerian state or what one would prefer to call the "garrison republic" is a product of the withdrawal of the state from social provisioning and absence of safety security nets. It is a product of neo-liberalism beginning with the International Monetary Funds (IMF) and International Bank for Reconstruction and Development's (IBRD otherwise known as World Bank) Structural Adjustment Program (SAP). Their medications of SAP which we stupidly accepted began the escalation of crises in peripheral capitalist political economy and the export of counterterrorism from these poverty-strike states to the core capitalist states in what Nassar [4] describes as the migration of dreams and nightmares. He said:

While the migration of dreams stems from cultural and technological globalization, a different process called the migration of nightmares is a direct result of global violence and terrorism.

Thus, neo-liberal globalization as Jamal Nassar [4] has indicated in the forgoing, has bequeathed to us globally the escalation of crises in both the core and periphery of capital in forms of terrorism and counter-terrorism. Above all, globalization or neo-liberalism has unleashed crises in the backward or peripheral capitalist societies but in its dialectical relations, neo-liberalism has equally stimulated crises at the core of capital resulting in the repressive state. Thus removing the capitalist state from its welfare role since 1945 to 1970 s, the capitalist welfare state turns a punitive state, thus neo-liberalism criminalizes the underprivileged, especially, the reserved army of the unemployment. As a result, the police institution world-wide turns from corrective agency to crime control state or repressive outfit serving the interest of advance capital and their local collaborators. In this process the hands of the police in a peripheral political economy of neo-liberalism are tied because of the interests of both the external and internal gladiators of its dialectics.

The state in the neo-liberalism criminalizes the reserved army of the unemployment. In a situation where the commonwealth is not for the common good, but is being pillaged by the dominant classes and their foreign mentors, the crises that evolve are as a result of the criminalized reserved army of unemployed always give birth to the various forms of youth crises. It could, in the extreme, give birth to low intensity conflicts and even civil wars which can stretch conventional policing beyond its capacity. The causations of extra-ordinary youth crises can only be found in our understanding of uneven-development paradigm in which the core of capital generates crises which it jettisons or ousters to the periphery. In this process, the underprivileged become the target as a result of extreme deprivation and instead of the state and its police institution to become rehabilitative they turn repressive and resort to crime control. To the root of the problem, the theory of uneven-development, we now turn.

\section{Theory of Uneven-Development and Youth Crises}

In the words of Aas [1] the contemporary global insecurities can be situated in the context of the deepening social divisions between the 'winners' and the 'losers' in the new world order resulting in the changing dynamics of social exclusions. Thus the neo-liberal economic model is marked not only by its great productivity dynamism, but also by the way it excludes large social sectors, territories and countries. Aas [1] Borja and Castells who pointed out the dual characteristics of the new global economic order which are its extra-ordinarily and simultaneously - inclusive and exclusive in nature. This situation that has been described by the foregoing authors is not new to capital, it is only deepening. Karl Marx had noted more than one hundred and fifty years ago that capital as a result of its production relations socializes production while surplus value (rents, profits and dividends) are privatized. This is capital's first dualism as the workers are paid necessary labor (wages and salaries) while the bourgeoisie swallow the surplus value leading to the immiserisation of the proletariat in the class struggle. What makes contemporary researchers to claim credit is nothing but the cult of regency or contemporaneity.

As such Aas [1] conclusion is that the foregoing situation has a network society in which the creation of value and intensive consumption are concentrated in segments that are connected throughout the world, while other population are moving from previous situation of exploitation to a new form of structural irrelevance. This he says are processes of exclusion of 'switching off taking place both on the global level by creating regions which are disconnected from global flows and on the national and local levels by creating 'switch off' regions, cities and parts of cities. Both structural irrelevance and switched off areas are not new to capital, it has been its eternal structures from birth. The other part of the global village is only disconnected in the global flows only in redistribution of surplus value generated in the global capitalist political economy. The West and indeed advance capital scoops off the surplus from the Third World in collaboration with its comprador bourgeoisie and returns little or nothing to it. This informs the dependency and underdevelopment paradigm. Our structural irrelevance in the redistribution question 
generates poverty, unemployment and extra-ordinary youth crises making the task of conventional policing difficult. The so-called switched-off areas are products of transfer regimes of capital from the extremities of capital to its core; a product of the deepening of the sorcerous fangs of vampire capital into the life arteries of its victims. Thus these areas are not switched-off areas in its totality, but are included in the production of global capitalist surpluses but excluded in its redistribution. It can be concluded without equivocations that global connections and disconnections and their local variants are the objective expressions of international capitalist political economy of uneven and spasmodic development which is the engine of structural violence against the dispossessed.

Thus Aas position that the global village is deeply divided is not new. Its historical origin has been determined about one hundred years ago by Lenin [5-9] in the development of capitalist imperialism, in what he called uneven-development in the emergent monopolyfinancial capital. Earlier on, Karl Marx had identified the process of the integration of these backward territories in the globalization of capital. In the words of Marx [10], "It is the tendency of the capitalist mode of production to transform all production as much as possible into commodity production", when the dictates of profits have prevailed or present themselves. Marx [10] also said of capital in the process of integration of the backward societies that:

Conquest may lead to either three results. The conquering nation may impose its mode of production upon the conquered people...or it may refrain from interfering in the old mode of production and may be content with tributes... or interaction may take place between the two, giving rise to a new system as a synthesis.... In any case, it is the mode of production-whether that of the conquering nation or the conquered or the new system brought about by merging the two-that determines the new mode of distribution employed.

However, in most of the underdevelopment countries, capitalism penetrated, left the old pre-capitalist structures intact but had to convert them in subservience to capitalist relations of production in the interest of Euro-America and Japanese capital [11]. This is where the dualist' theories of the petty-bourgeois and bourgeois economists, sociologists, historians are anchored. This is where Samuel Huntington's Clash of Civilisation is equally anchored ideologically. According to Shapera cited by Mellassuex [12] dualism should be seen as capitalist mode of integration of non-capitalist mode. It is, therefore, the unwillingness of capital to develop the backward societies and its willingness to keep them as the backyard of Euro-America and indeed Japanese capital that is the cause of this "deeply divided global village" or dualism as a major feature of globalization. It has been a major feature of capitalism from its inception. This was why Lenin [6-8] had to counter the views of those petty-bourgeois of his time that capitalism could transform all of society and also pre-capitalist societies. He said thus:... if it (capital) could raise the living standards of the masses, who in spite of amazing technical progress are everywhere still half-starved and poverty stricken, there could be no question of surplus capital. But if capitalism did these things it would not be capitalism; for both uneven-development and a semi-starvation level of existence of the masses are fundamental and inevitable conditions and constitute premises of this mode of production. As long as capitalism remains what it is, surplus capital will be utilized not for the purpose of raising the standard of living of the masses in a given country, for this would mean a decline in profits for the capitalists, but for the purpose of increasing profits by exporting capital abroad to the backward countries [7].
Lenin [7] further stressed that the uneven and spasmodic development are the objective features, conditions and processes of capitalism without which capitalism would no longer be capitalism but something else. Hence, the uneven-development between industry and agriculture, between labor and capital, and between the advance capitalist countries and the underdevelopment countries. The foregoing are structures that generate structural violence creating massive unemployment, under-development and through the Structural Adjustment Program (SAP) under Ibrahim Babangida, and his other accomplices, generating extra-ordinary youth bulge and crises deflected always into religious and ethnic conflicts overstretching conventional policing in Nigeria. This is a product of the global criminal economy of neo-liberalism [1]. The global criminal political economy is not just that of neo-liberalism but historically that of emergent capital of trans-Atlantic chattel slavery, colonialism, neocolonialism and now globalization. These have given birth to a peculiar type of state in post-colonial societies. This peculiar type of state generates crises and youth restiveness because of its abnormality.

Uneven-development has given birth to the abnormal state. The state is abnormal in the sense that the substructure is not in congruence with the superstructure of peripheral capitalism. In other words, it is not the internal class struggles in the economy and society that gave birth to the state; hence it is abnormal because it deviated from rules of state formation in the historical process. This is why the substructure is weak that is supposed to give strength to emergent superstructure/social formation of peripheral capitalism.

From the Greak's theory of the state as the quintessence of the good, to the current bourgeois theory of the state as social contract; such will not give as the true nature of the state and its class character [8]. It will not equally give us the deviations from the normal state in the abnormal state as a product of uneven-development and how it evolves the infrastructures of insecurity and crises in the developmental process. Lenin [8] emphasized that: ...the state has not always existed (from eternity). There is a time when there was no state. It appears wherever and whenever a division of society into classes appears, whenever exploiters and exploited appear.

If the dominant classes are endogenous and not exogenous, the character of a normal classical state is maintained, as such, internal stability in hegemonic control is assured. Such a state will prevent capital flight that is always done by classical capitalist countries through predatory and capital accumulation [13]. However, a state can grow from abnormality into normality when it has the capacity to retard capital flight. According to Chomsky [14], "One of the reasons for the radical differences in development between Latin America and East Asia in the last half century is that Latin America did not control capital flight, which often approached the level of crushing debt.... In contrast, during South Korea's remarkable growth period, capital flight was not only banned, but could bring the death penalty". Capital flight is one of the sources of Colleir's [1] sources of low income, slow growth and primary commodity dependent economy which make such countries prone to conflicts and civil wars. The structures of Paul Collier's economic analysis which instigate crises which he fails to acknowledge are indeed externally determined by advance capital, aided by internal comprador, or dependent capitalist classes.

Although Gavin Williams, in his edited book Nigeria: Economy and Society, did not mention the abnormal state but the feature he describes of the transfer regimes of the Nigerian state which go for every other African state and the underdeveloped world speak volumes confirming the abnormal state structures imposed on Nigeria and by 
extension Africa and the capitalist dependencies. This is what Karl Marx and Frederic Engels call the extremities of capital. In all capitalist social formations that lack sound industrial base but based on commercial or merchant capitalism like Nigeria, Africa, the Third World even in pre-capitalist Mainland Europe, crises of core capital are felt more in its periphery, which assumes various forms. Hence Marx et al. $[15,16]$ said:

While therefore, the crises first produced revolutions on the continent (Mainland Europe- my emphasis), the foundation for this, nevertheless (was) always laid in England. Violent outbreaks must naturally occur rather in the extremities of the bourgeois body than in its heart, since the possibility of adjustment is greater here than there.

The characteristics of the abnormal state and its transfer regime create the crises of peripheral capitalism. Crises of peripheral capitalism are products of the nature of transfer regimes, capital flight and unequal exchange in the global division of labor. Much works in the hands of the police is as a result of our acceptance of globalization hook-line-and-sinker which is the Washington Consensus instead of the Asian Model. We have been deceived to believe that government must not have hands in business. The death trap of this type of reasoning is the tragic transfer regimes in dependent capitalist social formations which make economic transformations almost near impossibility. We have noted earlier Noam Chomsky's position that capital flight retarded Latin America's developments while the arrest of it strengthened East Asia's development. According to Mahbubani [17], the recent transformation of Asia has laid the foundation for peace in that continent. He failed, however, to state the key, the liberation of Asian states to take on the normal state structures. As Chomskey [14] has noted the Asians have taken control of their capital for development and to a certain degree prevented capital flight. However, for Nigeria and Africa, the opposite is the case because of the nature of the transfer regimes. Williams [18] exposed this thus:

In Nigeria, the state has promoted the development of capitalism, foreign and domestic, by shifting resources from more competitive to less competitive producers, from craft to factory production, from the poor to the rich and from Nigerians to foreigners. It has hardly given free rein to the ability of the people to produce goods. It has promoted the wealth of the nations (some nations- my emphases); but only by the impoverishment of the people.

\section{The Dialectics of Youth Bulge, Crises and Policing in Nigeria}

In a conference proceedings published by CLEEN foundation in 2011, the youth were estimated in 2006 record to constitute 34 percent (45.4 million). In recent estimate, they were said to constitute about 40 percent of the nation's total population estimated to make up some 54-55 million [19]. This is supposed to be the most vibrant segment of the population. In societies of colonial and neo-colonial heritage this supposedly vibrant part of the population is always wasted because of the political economy of imperialist globalization of transfer regimes or the crises of the global redistribution question. We have noted earlier in this work Gavin Williams transfer regimes that sent wealth from the dependencies to the metropolitan countries or homes of EuroAmerican and Japanese imperialism. Chinweizu [20] said of the emergence of neo-colonialism in Africa thus: among the new legal chains placed on the petit- bourgeoisie that inherited paper independence, where a whole battery of international conventions sanctioned by something called international law. The would be independent countries signed to uphold all these laws before power of paper sovereignty was handed to them. They signed to protect multinationals whether they were stealing our wealth, or even they starved or killed us was not the matter but international law must be upheld for Europe and North America to get more milk to fatten [20].

The foregoing was against the dynamics of the pioneer capitalist industrialized nations wool exports, the raw material thus retained in England was processed into finished woolen cloth by the newly empowered English woolen cloth manufacturers, thereby creating wealth at home, with all its multipliers effects, which over time made England (or Britain) the richest country on earth, a country envied and emulated by others [21,22]. Prior to the rise of industrial England as a result of Queen Elizabeth I blanket ban on export of raw wool, Malthus had theorized of over populated England. The pre-industrial youth bulge in England and the fear of earth carrying capacity makes Malthus to fear the carrying capacity of the earth that while food production was growing at arithmetical progression in England; population was growing at a geometric progression. Thus Malthus said that if rapid population growth is not checked there will be a crisis of resources availability to meet the needs of the population. Its later day adherents, the neo-Malthusians locate all economic developmental problems and those of the environment on population [23]. In this respect, the youth bulge in Ogoni land, a product of the completely polluted Ogoni soil would be blamed on overpopulation. Equally, the degradation of Ogoni soil and that of the entire Niger Delta is a product of pollution orchestrated by the various multinational oil companies' drilling in the Niger Delta [24]. In this respect, both the Malthusian and the neo-Malthusian models known as the pessimists would not serve our purpose but rather the optimist or the alternative model which would make us to grasp properly the youth bulge phenomena in Nigeria and beyond [23].

The pessimist's fear of overpopulation is a product of the fear of the earth's carrying capacity and also the increasing fear of the limited nature of earth's resources. Both the Malthusian and the neoMalthusian fears appear unfounded since the population of Britain in Malthus' time which stood at 10 million mouths has accelerated by $600 \%$ to over 60 million souls by today. Despite this support of empiricism against vulgar theory and practice, the Africanist adherents of the Malthusian and the neo-Malthusian model would not allow us a respite as regards the issue of overpopulation in Nigeria and Africa. These pessimists assert that rapid population growth, in this case, the youth bulge hinders the growth of income per capital, thereby reducing the rates of savings and investments, thereby aggravating mass underemployment, unemployment and poverty. Whereas, the optimists are of the conviction that population growth can stimulate both technological change and the adoption of techniques in realising economies of scale, and as a result promoting economic growth. The debate between the two opposing schools does not concern us here. What is of importance to us here is the implications of the youth bulge and its dialectics on youth crisis and the implications of the crisis on conventional policing.

Whereas it took 200 years for world population to double itself after 1650 , it took 100 years to double after 1850 . Thus the pessimists see the origin of all world pressing economic problems as resulting from the ever-increasing pressure of population on the limited material resources of the earth in many regions leading directly to hunger, poverty, disease and political unrest within states [25]. As with the tradition of capital, the dialectical connection between its internal crises of greed, its international spread in greed is always obscured in 
turning reason upside down. It goes on blaming lack of savings for little or no investments, in blaming population for all the ills of Third World's underdevelopment, in blaming corruption, the internal child's play of capital in the Third World instituted by international financial capital which dupes their dependencies in the current world of globalization as the issues. It now sees youth bulge in the backward dependencies as the cause of the crises in these underdeveloped societies and the cause of the difficulties of conventional policing. Alexander [26] thus said:

The myopic refusal to confront capitalist production as a harsh mode of exploitation which perpetually reproduces inequalities through division of labor, work discipline; the wage relations itself, ultimately prohibits this school of thought from leading to the eradication of inequality.

It is not inequality alone it obscures, it equally obscures terribly the world historical process and how it generates crises and crimes now in this age of globalization. It obscures the rest of us outside the Western hemisphere from understanding the crises visited on us continually from the trans-Atlantic chattel slavery, through the so-called legitimate commerce, colonialism, neo-colonialism and how its fiendish vampires blood- sucking tentacles have persisted. This creates the unevendevelopment that we talk about in our theoretical perspective and it equally creates the abnormal state resulting in the incapacity of the Nigeria state to handle the security crises vitiating the capacity of the Nigerian police from effective and efficient policing. It has turned the Nigerian state and indeed all states under the criminal economy of globalization turning from the welfare state and corrective policing to the repressive state and crime control policing because of the increasing accumulation of surplus value through criminal global accumulation process. It is because the state has removed itself from providing for the good of the commonwealth but rather assisting and defending private wealth. This is the source of the youth bulge and the extra-ordinary youth crises in Nigeria and beyond which has now overstretched conventional policing in Nigeria and across the globe. Even in the advance capitalist countries the Washington Consensus Model putting the state out of socio-economic governance or basing everything on private sector dominance and control of the economy resulted in the 2008 so-called financial crises in the West [27].

The youth bulge, therefore, is a part of the population question. The Malthusian and neo-Malthusian see population control as cure-for-all maladies. In this respect, Potts and Selman [28] said "In recent years there has been a tendency for family planning to be seen either as a cure-all for the problems of the world, or as a dangerous irrelevance, diverting us from the true task of eliminating poverty through economic development". As such youth bulge could be seen by the pessimist as a result of lack of birth control but this is not the whole truth. It is a product of relative overpopulation. In capitalist societies, however, relative overpopulation is occasioned by the process of capitalist accumulation in which relative surplus value may be expanded bringing about unemployment or relative overpopulation [9]. Relative surplus value is the surplus which the capitalist get as a result of constant modernization or revolution in technology which has its own dynamics, that of shedding off labor leading to large unemployment or underemployment which Karl Marx calls "the reserved army of the unemployed" or relative overpopulation [23].

The unemployment and the underemployment dynamics in Nigeria and other backward countries are occasioned by the negative impacts of the industrial economies on the dependent, underdeveloped raw materials economies. This has always resulted in a type of relative overpopulation in the backward societies. The penetration of capital into Nigeria, Africa and the backward societies of the extremities of capital disarticulated their pre-colonial political economies to serve the interest of monopoly financial capital or imperialism. The imposition of capitalism of uneven-development brought into existence the dehumanizing conditions of poverty. Thus the seeming overpopulation in Nigeria and indeed in Africa is a creation of the penetration of capital into Africa and is relative to the means of employment generated by the system, and not to the means of subsistence as Malthus posited [23]. The size of the working class and indeed employment and the reduction of the youth bulge depends on the primacy which the economic system places on the accumulation process and the industrial base the system is able to generate to reduce unemployment and therefore the youth bulge. This Nigeria is not doing to reduce youth bulge and crises, thus placing a greater burden on policing.

We have noted earlier that the relatively superfluous population or surplus labor force constitute what Karl Marx calls an "Industrial Reserve Army" which is necessary for the continuation of the production of wealth or accumulation on a capitalist basis. In the first place, the presence of the "reserved army of unemployed" makes it possible for the capitalist to use the threat of unemployed to manipulate his labor force to overwork them-selves more than expected. Secondly, in the period of scarcity, the reserve army can be manipulated to increase productivity [29]. Since capital through uneven-development refused to revolutionize technology in Africa, its penetration created and continues to create "disposable Industrial reserve army". In pre-colonial Africa, there was nothing like surplus population what existed was some degree of equilibrium between man and nature. There was also some labor shortage rather than labor surplus population [29]. However, this was to change overnight with the presence of colonial capitalism which shattered the balance and created overpopulation as was the case of the Kikuyu [29].

In other areas where lands were not alienated from the peasantry during periods of colonization, the tillers of the land were forced by the nature of the colonial political economy to devote a substantial portion of their land and labor power for the production of export crops at the expense of the food crops which they needed [29-32]. For the extractive industry and construction, the colonizer broke the resistance of the peasantry through forced labor or by inducing migration through the imposition of taxes. In extractive industries such as mining, the African lands have been devastated and the rendered superfluous. The cases of tin mining in Jos, Plateau state and in Ogoni land and the entire Niger Delta where decades of oil explorations and exploitation have devastated the land and the population rendered superfluous amongst others are some of the examples. In these cases, pollutions and devastations of the lands have resulted equally in youth bulges and indeed superfluous population.

In Africa, the objective interest in globalized capital and their local African collaborators in the accumulation process have been to reproduce these conditions resulting in superfluous surplus population. Most population expert of the Malthusian and neoMalthusian callings would not take these factors of relative overpopulation and indeed youth bulge into account. These facts result in unemployment and youth crises across the globe and mostly in the underdevelopment countries creating problem for conventional policing. The international labor organization (ILO) Annual World Employment Report, 2004-2005 cited by El-Gawady and El Din said "unemployment is one of the biggest threats which faces the Middle 
East. The unemployment rate was estimated at $15 \%$ to $20 \%$ in the year 2004. The President of the World Economic Forum, Klaus Schwab also "...warned that unemployment in the Middle East was a time bomb that would require the creation of 100 million jobs in the next 10 years to diffuse it".

According to the International Labor Organization as cited by El Gawady and El Din, the average unemployment rate across the globe reached $6.2 \%$ but in the Arab region it was 12.2\%, and increases every year by $3 \%$. The report predicted that the number of the unemployed people in the Arab region will reach 25 million in the year 2010. The report also noted that the number of unemployed world-wide climbed to new heights in 2005 despite a robust economic growth of that year, as jobless workers stood at 191.8 million globally. The misdistributions of income across the global and even in the advanced capitalist countries have resulted in crises in the nations of classical capital. Stieglitz [33] said that unsustainable income inequality is leading to other big problems. It was his pre-Wall Street protest assessment of US political economy of big business. He said 1\% Americans control 40\% of the US economy, the basis of the Wall Street protest and occupation, a protest claimed to have been carried out on behalf of the remaining $99 \%$. This is a product of neo-liberalism whose dynamics has rendered many very poor in its philosophy (as usual) of the survival of the fittest built on the Washington Consensus Model.

In the words of Aas [1], the result of this is the emergence of the global criminal economy. We have noted earlier that this type of economy that is criminalizing the poor, principally, the youth has brought about the repressive state which has replaced the welfare state. In the welfare state, the state was concerned with the rehabilitation and correction of deviants through the police and other corrective social institutions. In the repressive state policing is about crime control, a process brought into being by the criminal global economy of neoliberalism. It has resulted in the increase of prison population of many parts of the world in which the United State is leading with 2.19 million followed by China with 1.55 million and Russia with 0.87 million out of a total population of more than 9 million people in prisons worldwide [1]. Aas [1] also noted that privatized policing and prisons have sprang up even in the advanced states of capital to put up with the deluge of criminal activities of the deprived by globalization or neo-liberalism.

The impact of globalization on youth bulge and indeed unemployment is very pathetic in Nigeria. According to the National Bureau of Statics (NBS), the unemployment rate climbed from $19.7 \%$ in 2009 to $21.1 \%$ in 2010 and stood at $23.9 \%$ in 2011 . The rate is higher in rural areas (25.6\%) than in urban area (17.1\%). The NBS (2011:13) has equally given us global spread of unemployment in some countries across the world. The report noted that, that of USA rose from 5\% 2007 to $9 \%$ in 2011 ; Spain from $8.6 \%$ to $21.52 \%$; UK from $5.3 \%$ to 8.1 . Ireland currently stands at $14.3 \%$ from $4.89 \%$; Latvia from $5.4 \%$ to $16.5 \%$; Greece from $8.07 \%$ to $18.4 \%$; Italy from $6.7 \%$ to $8.3 \%$ the average of the Euro zone is said to be $10.7 \%$. In Africa, South Africa and Angola are ahead of Nigeria with 25\% apace; Botswana 17.5\%; Egypt at $11.8 \%$; Kenya at 11.7 percent while Namibia is leading Africa with $51 \%$.

One can be sure that most of those unemployed are youth and the most vibrant of the population across the globe. In Nigeria 3.2 million that came on stream in the tertiary institutions in 2006 and 2007 were expected to enter the job market in 2010/2011. This number did not include the drop outs from secondary levels for various reasons and entered the job market in the rural and urban areas out of the 21 million that enrolled in 2006 and 2007 [34]. Taking 2010 as year of the beginning of the devastating appearance of Boko Haram and taking into cognizance that this sect began with the tearing of their certificates, meaning that the Whiteman's learning is forbidden, one can assume that the threat of unemployment must have been responsible for this youth revolt against Western education, starting in Borno State, spreading across the North East and reaching almost the entire North making the job of conventional policing difficult. Prior to the emergence of Boko Haram, the neo-liberal globalization that has killed job opportunities resulted across the country in the emergence of many security outfits because of the increase in insecurity in the country. From the police, splintered security agencies have emerged and other new ones which have been created such as federal road safety corps, civil defence, we now hear of one so-called Peace Corps, not taking into account many private security outfits that have been born because of the excruciating economic conditions of neoliberalism. These are indications that conventional policing is becoming increasingly more difficult.

An Eminent Nigeria Social Scientist, indeed a Political Economist of blessed memory, Claude Ake consistently hammered into our ears that, "It is the foolishness of the ruling class that leads to a revolution." One of the sign of failed state or failing state is the inability of security agencies to cope with the internal security issues. The incapacity of police in the task of maintaining security under the terror of Boko Haram is not in doubt. In general, security crisis before our very hands is confronting us in a very deadly war in suicide bombings, militancy, armed robbery, mammoth corruption amongst others. If the youth crisis is resolved, other vices will go. However, youth crisis cannot be resolved without taking control of both the global roots and the local dynamics of the criminal political economy of corruption. Human Rights' Watch publication 2008, titled Nigeria: World Report gave earnings from crude oil from 1999 to 2007 at a total of $\$ 223$ billion and also between \$4-8 billion stolen annually [35]. National Bureau of Statistics [34] gave earning from 2007 to 2010 at $\$ 196$ billion. Since these earning were not used to address unemployment of the youth put at over $23.9 \%$ in Nigeria, the crisis of the youth and the crisis of conventional policing cannot be papered over. The Arab youth unemployment that was estimated between $15 \%$ to $20 \%$ and indeed average of $12 \%$ is seen as a time bomb by the international labor organization (ILO). Nigeria's about $24 \%$ and what is that? If nothing is done to check this, the task of conventional policing will continue to be very difficult. Those who put our money into their pockets in the name of God has blessed us are the criminals and are making the job of conventional policing increasingly difficult.

\section{Neo-liberalism, Strengthening Class Formation, Youth Crisis and Convectional Policing in Nigeria}

Those of us who are over Christian and over Muslim see the youth crisis in Nigeria expressed in armed robberies, kidnappings, militancy, Boko Haram amongst others as the work of Satan. The fact remains that every one of us hates Satan but ironically we all, what one meant by we all, are those in leadership position, do what Satan wants. Yet we sermonize against corruption and other vices against humanity and yet we are neck-deep in them. An illustration suffices here. A friend told me of a marriage that was about thirty years old and the woman constantly pressured the husband for marriage blessing commemoration. The husband resisted at first but after much pressure he had to cave in to the wife. On the blessing day, the reverend father asked the woman; "will you renounce the devil and his angels to keep 
up your solemn matrimony?" The wife gladly responded, "With all my heart, so help me God ". On the turn of the man the same question was asked first, second and third time! And the man kept quite! The reverend gentleman asked the man, are you not the one I am talking to? The man retorted, "See the devil by my side and you are saying I should renounce it! If I renounce her will you take her? In Nigeria, the devil is the leadership. The leadership has led us into a 30 month agonizing civil war, created the environment that led to failed First Republic and now a wobbling Fourth Republic".

The crises of Nigerian state (what one has earlier described as the abnormal state) result from the lack of congruence between the substructure and the superstructure. It is a crisis of economy and society (substructure) and the social formation (politics, philosophy and the belief system, all known as the superstructure) which crises pose a very serious contradiction. In his seminal work Alavi [36] saw the post-colonial state as a product of the imposition of colonial rule by the metropolitan bourgeoisie, as we have noted earlier. This process of creating the dependent or the abnormal state helps the metropolitan bourgeoisie to exercise dominion, over all the indigenous social classes, a dependent social class that owed their existence to raw material dependent political economy. We have somewhere in all classical state beginning with the slave state that rose from the ruins of the primeval society or primitive communal system, through feudalism that replaced the slave state and now capitalism or capitalist state and now even the comatose socialism, the state rose out of those societies and nor externally imposed.

The external roots of the colonial state and the neo-colonial state determine its character and class structure. Weber [37], said that class formation does not depend only on market relations. He is of the view that it depends equally on status groups, occupational groups and skills. Despite Max Weber's use of the concept of class, his classification and categorization of class did not afford us a clear cut understanding of the place of property relations in the determination of classes. As such, his position on class and class formation would not help us to understand class structure and class formation. The economic does indeed have the determinant role in a mode of production of a social formation but the political and the ideological (combined making the superstructure) also have a very important role $[38,39]$ which Karl Marx, Fredrick Engels and Mao Tse-tung made clear. Without this structural approach to class analysis, class dynamics and class formation, it would be difficult to place the African and indeed the Nigerian dependent (landed/rentier) dominant classes as they do not in the real sense own the means of production but as gate keepers for imperialism they are cued into it. They only have access to the means of production because of the place they occupy in the imperialist chain, in the power equation of their various countries. Lenin [6] defines social classes thus: ...large group of people differing from each other by the place they occupy in a historically determined system of social production, by their relations (in most cases fixed and formulated in law) to the means of production by their role in a social organization of labor, and consequently, by the dimensions of the share of social wealth they dispose and the mode of acquiring it. Classes are groups of people one of which can appropriate the labor of another owing to the different places they occupy in a definite system of social economy.

Implicit in Vladimir Lenin's definition of classes is the structural determination of social classes as he did not limit himself to the positional (economy) aspect of classes but takes it to the realm of law which includes politics and ideology. In this regard therefore, we agree with Poulantzas [38] view that structural determination of classes must be distinguished from class position in each historical epoch or social formation. He stressed "...the importance of the political and ideological relations in determining social classes and the fact that social classes only exist in the form of class struggle and practice. $\mathrm{He}$ warned that class determination must not be reduced to a voluntaries fashion to class position [38]. It is from this structural class position that we define the comprador/land/rentier classes in their structural dynamics of class formation and relations in Nigeria. The Nigerian dominant classes are not just political class but in politics and ideology they are capitalists, as such, they can be seen to be so.

The class formation in Nigeria was a product of the integration of the peasant economy into the world capitalist system for the supply of raw materials to the metropolitan capitalist economy. As such, Nigerian was encouraged to develop the raw material agricultural economy for export purposes in the name of the so-called theory of comparative advantage. In the view of those who believe in the foregoing theory, we have to produce export or cash crops for foreign exchange we would earn for national development. The establishments of such structures were accompanied by the ouster of merchant capital from the metro poles into the colonies. Thus a division of labor was enacted between merchant capital or trading capital and industrial capital after the intra-class struggles, between them and with the victory of industrial capital over merchant or trading capital [31]. The settings of the domain of merchant capital in the colonies was what made Oliver Stanley, a British Colonial Official desired a warped 'Economic Independence' for Nigeria, a sort of Economic Independence the British themselves rejected under King Henry VII and VIII and under Queen Elizabeth I [21,22]. According to Nkrumah [39] the way to achieve this economic independence according to Stanley's thinking, is for the Nigerian people to produce more cocoa, more palm oil, more cotton, more rubber, and more and more raw materials for the British manufacturers and industrialists, who, incidentally, pay for these raw materials at their own price.

What the British rejected by placing a blanket ban on exportation of raw wool to the city states of Florence, Venice and the Dutch Republic and what made the Americans to go to war of independence, was what Euro-American civilization forced on the rest of us and we swallowed the bait hook-line-and-sinker. It was the beginning, however, of the development of the Abnormal Nigerian and Third World States which resulted in the incongruence or disjuncture between their substructures and the superstructures. This type of state produced a vitiated class based on mercantilism becoming agents of trading capital of the Royal Niger Company later the united africa company (UAC), John Holts, GB Ollivants, SCOA, CFAO and many others. This is how the colonial state, according to Alavi [36] created the state apparatus through which they exercise dominion over all indigenous social classes. This was the beginning of class formation in Nigeria, Africa and indeed all the colonial dependencies.

With the emergence of independence, politics became avenue for class formation. In the classical states, classes were product of economic exploitations and class struggles. In other words, classes emerged from the struggles in the economy and society, that is, class struggles at the substructure but contrary was the case in the neocolonial abnormal states. The trading or merchant capitalists though still exist with their African agents who were just mere distributive outlets and agents for raw material purchases while those in political authorities seek to acquire wealth through politics which were adequately documented by Okwudiba Nnoli in his book Ethnic Politics 
in Nigeria. As such those in politics plunged themselves into primitive accumulation which was why politics became a do-or-die affair or a life-and-death matter in the First Republic [40]. One is in doubt whether anything has changed at all! Whether in military politics or in civil rule being tagged democracy from the Second Republic, through the aborted Third Republic to today's Fourth Republic, the sing-song in class formation is what Karl Marx calls primitive accumulative of capital.

Primitive accumulation which started with ten per-centers of the First Republic blossomed during the civil war through shoddily executed contracts to feed soldiers in the war fronts and equally under paid non-commissioned officers (soldier's) salaries from which both contractors and senior military officers profited. In the post-civil war Indigenization Exercise, the so-called Operation Feed the Nation which made military officers and their class in civil society to corner vast lands through the Land Use Decree under Olusegun Obasanjo's military regime amongst others was also a case in point of corruption. The preparation of the indigenous comprador bourgeoisie to take a greater share from the national cake without production was moving apace with time. Under the Second Republic mammoth corruption was made under Shehu Aliyu Shagari- 1979 to 1983 . As such the ground was properly prepared for jumbo corruptions of the structural adjustment Program (SAP) under Babangida's military regime. The international monetary Funds (IMF) and International Bank for Reconstruction and Development (otherwise known as World Bank) policies of murderous devaluation of the naira, commercialization, privatization and lean government through retrenchment of public sector workers led the way to hyper-primitive accumulation of capital.

The emergence of the 'superfluous' population in Western Europe, the population thrown of the land because of the Enclosure Act for capitalist plantation agriculture were absorbed by the New World as indentured servants [41]. In Western Europe, principally in England and France, relative over population of Malthus time was relative to the means of employment which was jettisoned to the New World which absorbed those surplus populations thereby relieving the metro poles of their relative superfluous population. In Nigeria and indeed Africa, that opportunity has been absent. No colonies to export their surplus or superfluous population to and hence indeed the youth bulge question. The current state of the youth bulge is aided by the nature of the Nigerian political economy that is raw material dependent, which create jobs for the processors of the raw materials in the metro poles and unemployment here in Nigeria, Africa and Third World, the basis of the youth bulge.

From the First Republic to date, the process of class formation and the relation of the dominant class to their foreign mentors and the corruption involved in the class formation as of primitive accumulation of capital have hindered the growth of the economic transformation of Nigeria. It has hindered the process of job creation thus intensifying youth bulge. It has escalated the vices in the youth which we say are "Satanic" from armed robbery, kidnappings, the intra and inter-religious crises, regional militants that now resort to primordialism in identity 'reformation' such as Egbesu Boys, Arewa Youth Forum, Odua Youth, Movement for Survival of the Sovereign State of Biafra (MOSSOP), Movement for the Survival of the Ogoni People (MOSOP), Movement for the Emancipation of the Niger Delta (MEND), Niger Delta People's Volunteer Force (NDPVF), religiously tainted Maitatsine and Boko Haram amongst others. The emergence of all the foregoing is a product of a failed or failing state. The Nigerian state started failing even from the First Republic with the collapse of regional revenue bases after Korean War boom in international commodity prices and their subsequent collapse thereafter resulting in the crises of the First Republic deflected into primordialism $[42,43]$. The mammoth corruption of the ten per centers rocked the First Republic from the little internal left overs by imperialist forces.

With the discovery of crude oil which became the dominant source of national revenue and indeed foreign exchange earner, Nigeria took a jumbo ride into corruption in class formation. Watts [24] said, "To compile an inventory of the achievements of Nigerian petrodevelopment is a salutary, if dismal, exercise: 85 percent of oil revenue accrues to 1 percent of the population". Michael Watts cited former World Bank Chief Paul Wolfowitz who said that at least $\$ 100$ billion of the $\$ 600$ billion in oil revenue accrued since 1960 have simply gone missing [44-46]. He equally cited Nuhu Ribadu, the former Chairman of Economic and Financial Crime Commission (EFCC) as having claimed that in 2003, 70 percent of the country's oil wealth was stolen or wasted; by 2005 it was "only" 40 percent. By most conservative estimates, almost $\$ 130$ billion was lost in capital flight between 1970 and 1996. Over the period from 1995 to 2004, the per capita income fell from \$250 to \$212 while income distribution deteriorated markedly. Between 1970 and 2000, the number of people subsisting on less than one dollar a day in Nigeria grew from 36 percent to more than 70 percent, from 19 billion to a staggering 90 million [24].

Taking into cognizance that the introduction of Structural Adjustment in the mid-1980s followed by massive retrenchments occasioned by World Bank and IMF conditionality, the average conditions of the living standard of Nigerians have plummeted very badly. It began prior to SAP with Shehu Shagari's Austerity Measures. The Austerity Measures provided foot soldiers for Maitatsine from the unemployment and underemployed youth. In each of the Maitatsine crises against the state, the police could not cope and soldiers had to be drafted in to save the situation. The numbers of youth as foot soldiers radically increased with the introduction of Structural Adjustment Programs, with many families in the public sector losing their jobs. Unemployment situation in Nigeria is said to be about $24 \%$ that of the Arab World is between $15 \%$ to $20 \%$ and an average of $12 \%$. This Arab unemployment is what the International Labor Organization calls a time bomb and when it exploded in the North Africa region, it was beyond their policing. The signs that Nigeria's policing despite the increases in police recruitments day-in-day-out cannot cope are very clear. The evidence indicates that the strains in policing are enormous and as such their capacity as internal security institution has been compromised in coping effectively. As such private security outfits have sprang up all over the country. Rich individuals and some groups of people have decided to secure themselves as they have lost faith in the police. Even governments at various levels are creating different security outfits [47-49].

Much work in the hands of the police is as a result of our acceptance hook-line-and-sinker the Washington Consensus instead of the Asian Model. The Washington Consensus says that governments need not to be in business, that all government businesses must be privatized. The Asian Model is the contrary. The increases from 36\% to more than $70 \%$ put at 19 million to a staggering 90 million people from 1970 to 2000 subsisting on less than one dollar a day is a product of the local criminal economy. The increases in youth violence, armed robbery, kidnappings, increasing militancy, thefts and now Boko Haram have stretched the police beyond its capacity. From the introduction of Structure Adjustment Program (SAP) that resulted in many so-called religious crises in the 1980s to the 1990s, to the Niger Delta Crisis and 
now the Boko Haram resulted in extra-ordinary youth crises or youth bulge. The Amnesty granted by the Nigerian State under Shehu Musa Yar'Adua to the Niger Delta militants was for the restive youth of the geo-political zone. All those who came out to lay down their arms were the youth. To borrow the words of International Labor Organization (ILO) we are sitting on a time bomb, the youth crisis and the combined force of the Nigeria Police is yet unable to cope at this stage of skirmishes not to talk of their degenerations to mini-civil wars or low intensity conflicts such as the Boko Haram [50].

\section{Conclusion}

The youth crisis has been a global phenomenon and a product of the jettisoning of the state from social provisioning. It is a product of the processes of the concentration of wealth in the $1 \%$ of the population. This phenomenon has been the inner kernel of neo-liberalism and has created the superfluous population and equally the youth crises all over the globe. Even in the advance countries, the security crises it has generated is criminalizing the under-privileged resulting in a lot of crimes stretching internal security of the advance countries even with their advance electronic security gadgets beyond the scope of conventional policing. It has resulted in the privatization of internal policing giving rise to many private security outfits and in the privatization of prisons in United State. Globalization, a dynamics of neo-liberalism is causing the rise in criminality because of the increasing mass poverty of the rejects of the earth. This is happening today in the citadel of capital because neo-liberalism has created uneven-development or switched-off areas which Aas said is the main dynamics generating crimes across the globe which is increasingly tasking conventional policing resulting in the privatization of policing and even prisons in the advance countries.

The same global dynamics of neo-liberalism is playing itself out in Nigeria. Since Austerity measures imposed by Shehu Shaagari through the Structural Adjustment Program of Badamasi Babangida to date, since the forceful removal of the state from social provisioning, the massive unemployment and underemployment have created youth bulge that have resulted in the emergence of various youth groups. In the 1980s and 1990s the youth became the foot soldiers for the Maitatsine sect which was at each turn of eruption beyond conventional policing. Soldiers were drafted in to restore order. It has the same thing during SAP crisis, the unemployed and underemployed youth became 'converted' to religious adherents overnight turning such crises into religious crises and equally the police in most cases were caught pants down. The youth bulge as a result of the superfluous population has given reigns to anarchy across the country in the forms of the Niger Delta conflict, kidnapping, armed robbery, Boko Haram amongst others. It also gave rise to regional youth groups such as Arewa Youth, Odua Youth, and the Movement for the Actualization of the Sovereign State of Biafra (MASSOB) amongst others. This group has equally made the task of policing daunting.

Arising from the pervasive nature of crime in Nigeria today as a result of the withdrawal of the state from social provisioning, the welfare state has turned into a repressive state. However, this is not peculiar to Nigeria. The police have equally turned to crime control instead of as a corrective agency as it were in the welfare state. No remedy can be found in the state and the police becoming increasingly repressive. Those who told us that we must privatize to our wives kitchen have suddenly turned around to bail out their ailing private companies (such as the United States, Britain, France, Germany amongst others). This has been happening since 2008 after the so- called global financial crises. Suddenly, the Washington Consensus group has turned to the Asian Model. Surprisingly, government of the neo-liberal apostles has decided to swallow their vomit. But, we are stubbornly pressing on with a global failed agenda and unlike the Asians that have designed their own consensus jettisoning that of Washington and indeed the entire Western booby-trap, we are neckdeep in, sermonizing globalization and its neo-liberal characteristics of privatization and commercialization. This approach has led to massive unemployment and under-employment and the extra-ordinary youth crises making the task of conventional policing very difficult. In this quagmire of insecurity, the way forward is not more policing but development to absorb the teeming unemployed and under-employed, the reservoir of crime occasioned by neo-liberal economic policies.

The primacy of the economy in the security calculus we seem to be neglecting. Robert McNamara said "In a modernizing society, security means development. He said 'security is development and without development, there can be no security." He went further to state that “... any country that seeks to achieve adequate military security (also internal security policing-my emphasis) against the background of acute food shortages, population explosion, low level of productivity, fragile infrastructural base for technological development, inadequate and inefficient public utilities and chronic problem of unemployment, has a false sense of security". A repressive state cannot solve these problems; it would rather compound crime rates and impose more problems on conventional policing. The criminal economy must be reversed to create room for welfare, and then the police will revert to its corrective value instead of crime control value. We the elite and indeed the ruling class that have collectively duped the youth in league with imperialism are the anchor of the youth bulge and youth crises inhibiting conventional policing in Nigeria.

\section{References}

1. Aas KF (2007) Globalization \& Crime. SAGE Publication Ltd, London.

2. Colleir P (2008) The bottom billion: Why the poorest countries are failing and what can be done about it. Oxford University Press, New York.

3. Collier P (2009) Wars, Guns \& Votes: Democracy in dangerous places. The Bodley Head, London.

4. Arowosegba JO (2009) Violence and National Development in Nigeria: The 5. Political Economy of Youth Restiveness in Niger Delta. Review of African Political Economy 36.

5. Nassar JR (2007) Globalisation and Terrorism: The Migration of Dreams and Nightmares. Rowman \& Littlefield Publishers Inc, New York.

6. Lenin VI (1974) Collected Works. Progress Publishers, Moscow 29.

7. Lenin VI (1983) Imperialism, the Highest Stage of Capitalist. Progress Publishers, Moscow.

8. Lenin VI (1985) The State. In: Borison EF, Libman GI (eds.) Reader on Social Sciences; ABC of Social and Political Knowledge. Progress Publishers, Moscow.

9. Marx K (1986) Capital: A critique of political economy. Lawrence and Wishart, London.

10. Marx K (1970) A contribution to the critique of political economy. International Publishers, New York.

11. Tadheke MEU (1984) The oil industry and nigeria's dependency. University of Jos.

12. Mellassoux C (1972) From Reproduction to Production: A Marxist Approach to Economic Anthropology. In: Wolpe H (ed.) Articulations of Models of Production: Essay from Economy and Society. Routledge and Kegan Paul Ltd, London.

13. Reyna SP, Downs RE (2005) Deadly developments, capitalism, states and war. Taylor \& Francis e-Library, Singapore. 
Citation: Tedheke Moses EU (2016) Youth Crises and Conventional Policing in Nigeria: A Political Economy Analysis. Arts Social Sci J 7: 167. doi:10.4172/2151-6200.1000167

Page 10 of 10

14. Chomsky N (2011) Crisis and Hope: Thiers and Ours. In: Best R (ed.) The Global Industrial Complex: System of Domination. Lexington Books, New York.

15. Marx K (1977) Engels, Selected Works vol I. Progress Publishers, Moscow.

16. Marx K, Engel F, Lenin VI (1977) On Dialectical Materialism. Progress Publishers, Moscow.

17. Muhbubami K (2011) Can Asians Think. Marshall Cavendish Reprint, Singapore.

18. Williams G (1976) Nigeria: Economy and Society. Rex Collings Ltd, London.

19. CLEEN Foundations (2011) The challenges of youth restiveness, violence and peace in Northern Nigeria. Conference Proceedings.

20. Chinweizu (1978) The West and the rest of us. Nok Publishers, London.

21. Chang $H$ (2008) Bad samaritants: The myth of free trade and the secret history of capitalism. Bloomsbery Press, New York.

22. Reinert ES (2009) How rich countries got rich and why poor countries stay poor. Public Affairs, New York.

23. Tedheke MEU (2000) The united nations and population question in africa-an alternative view. A Journal of the Faculty of Arts and Social Sciences.

24. Watts M (2008) Curse of the black gold: 50 years of oil in the Niger delta. Powerhouse Groups, New York.

25. Lowry ST (1991) Pre-classical Perception of Economy and Security. In: Goodwill (ed.) Economics of National Security. Duke University Press, London.

26. Alexander S (1980) Introduction to Herzog $M$ from Hand to Mouth: Women and Piecework. England Penguin Book Ltd.

27. Blaney DL, Inayatullah N (2012) Savage Economics: Wealth, Poverty and the Temporal Walls of Capitalism. Routledge, New York.

28. Potts M, Selman P (1979) Society and Fertility. Macdonald and Evans Ltd, Plymouth.

29. Onoge OF (1983) On Correct Posing of the Population Question in NeoColonial Africa. In: Mabogunje AL (ed.) Population Dynamics and Economic Development. Unibadan Publishing Consultans, Ibadan.

30. Tedheke MEU (1982) The rubber industry and the under development of the peasantry: The case of ughelli local government area. University of Port Harcourt.
31. Tedheke MEU (1998) The West and the Distortions of Nigeria's Historical Process. In: Aderinto AA, Ubah CN (eds.) Nigeria and the Contemporary World. Nigerian Defence Academy.

32. El Gawady ZM, El Din MWK. Anti-unemployment Policies in Non-Oil Countries: Egypt, Jordan, Morroco and Tunusia.

33. Stieglitz J (2011) How unsustainable income inequality is leading to other big problems. US Pirg.

34. National Bureau of Statistics (NBS) Nigeria's Report 2011.

35. (2008) Human Right Watch.

36. Alavi H (1979) The State in Post-Colonial Societies: Pakistan and Bangaladesh. In: Goulbourne $\mathrm{H}$ (ed.) Politics and State in the Third World. The MacMillan Press, London.

37. Weber N (1973) Economy and Society. In: Gidden A (ed.) The Class Structure of Advance Societies. Hutchinson and Co. Ltd, London.

38. Poulantzas N (1975) Classes in Contemporary Capitalism. NLB \& Lowe and Brydone Printers Ltd, London.

39. Nkrumah K (1978) Towards Colonial Freedom. Panaf Ltd, London.

40. Nnoli O (1978) Ethnic Politics in Nigeria. Fourth Dimension Publishers, Enugu.

41. Williams E (1975) Capitalism and Slavery. Andre Dutch Ltd, London.

42. Bangura Y, Mutapha R, Adamu S (1986) Nigeria: A Republic in Ruins. Gaskiya Corporation Ltd, Zaria.

43. Tedheke MEU (2007) A Political Economy of Nigeria Civil War. Ahmadu Bello University, Zaria.

44. Boating O (2011) Cracking the Code: Unlocking Africa's Secret to Wealth.

45. Chomsky N (1995) Education as ignorance excerpted from Class Warfare. Chomsky info pp: 19-31.

46. Collier P (2012) The plundered earth: Why we must-and how we can manage nature for global prosperity. Oxford University Press, Oxford.

47. Engels F (1983) Origin of the family, private property and the state. Progress Publishers, Moscow.

48. Frank AG (1967) Ullysis Grant in capitalism underdevelopment in Latin America. Monthly Review Press, New York.

49. James CLR (1980) The Black Jacobins. Penguin Book Ltd, London.

50. Parenti M (1992) Imperialism. In: Hawkesworth M, Kogan (eds.) Encyclopedia of Government and Politics. Routledge, London. 